\title{
Attempts to Improve Xenodiagnosis: Comparative Test of Sensibility Using Rhodnius neglectus, Panstrongylus megistus, Triatomal vitticeps and Tridtomd infestans in Endemic Areas of Brazil
}

\section{Carlos José de Carvalho Moreira $/^{+}$, Alina Perlowagora-Szumlewicz}

Núcleol de Biologia| de Vetores e de Interação| Vetor/Parasito, Estrada da Covanca 56, 22735-020 Riol de Janeiro,

RJ, Brasil. Departamento de Medicinal Tropical, Instituto Oswaldol Cruz, Av. Brasil 4365」 21045-900

Rio de Janeiro, RJ, Brasill

From June 1984 to July 1992, 392 xenodiagnostic tests were applied on 264 patients with chronic Chngas disease from Brazilian endemic ureas of Virgem da Lapd and Coronel Murtal situated in the Jequitinhonha Valley, in the State of Minus Gerais.

The susceptibilities of Rhodnius| neglectus, Panstrongylus megistus, Triatoma vitticeps and Triatoma infestans were compared.

Most of the time 20 nymphs (fourth instar) of each species were applied to 161 women and 103 men aged between 5 and 83 years of age. The tests were prepared to compare the susceptibilities of two species at a time, using the same patients for each test.

Results showed a xenopositiveness of $26.28 \%$ (103 tests) being $27.98 \%$ in women (68positive in 243 applied tests) and $23.49 \%$ in men (35 positive in 149 applied tests). The relative frequency of xenopositiveness displayed a great superioritv of $\mathrm{P}$. megistus and $\mathrm{T}$. vitticeps. In tests from type I, for example, P. megistus was the unique responsible for $10.73 \%$ ofpositive xenodiagnosis vs. only $0.98 \%$ in T. infestans. Other parameters analized in this work confirm this superiority, and corroborate that T. infestans can be replaced by P. megistus and /or T. vitticeps in order to upgrade the efficacy of xenodiagnosis.

Key words: Chagas disease - xenodiagnosis - insect susceptibility - Rkodnius neglectus -

Panstrongylus megistus - Triatoma vitticeps - Triatoma infestans - Brazil

Chagas disease represents the main cause of morbidity and mortality in Latin America (sensu lato).

Up to now, xenodiagnosis used in screening chagasic patients, confirming the diagnosis of se-1 ropositive individuals, treatment control and stock isolation, is the most specific and sensitive technique currently available for diagnosis. However, this well documented technique described by Brumpt (1914) is considered a low sensibility method. In fact, the index of serologically positive patients is confirmed to be higher than the parasitologically ones (Avilla et al. 1993).

Segura (1987) demonstrated that xenodiagnosis applied to positive chronic pattients produced positive results in only 17 to $70 \%$ of the cases. This phenomenon can be explained by the fact that in the majority of cases, triatomine bugs were fed in

'Corresponding author. Fax: +55-21-280.3740

Received 8 December 1995

Accepted 4 September 1996 chronic patients having low numbers of circulating parasite forms.

Various studies showed different results depending on the species used (Cerisola et al. 197 1, Schenone et al. 1974, Alvarenga \& Bronfen 1984, Bronfen et al. 1984, Bronfen 1989, Pereira et al. 1993). Questions arose from these studies about the vector reliability as xenodiagnostic agents.

Some authors had already predicted that the efficiency of xenodiagnosis could be increased by using large numbers of bugs per patient (Meckelt 1964, Schenone et al. 1974, Cerisola et al. 1974); by repeatedly examining the patients (Castro et al. 1983) and by using significant epidemiological vectors in the same area where the patient lives (Dias 1940, Ryckman 1965, Little et al. 1966, Zeledónl 1974, Minter et al. 1978). However, interpreting results is difficult due to lack of standardization.

Cerisola et al. (1975) suggested for the first time the standardization of xenodiagnostic procedures, recommending the use of 40 third instar nymphs of Triatoma infestans as this species is associated with the domestic transmission of Chagas disease 
in Brazil. The above preference agreed with the polemic statement by Dias (1940), attributing greater susceptibility of the indigenous vector from the same geographical area as the patients. The exam would be performed after a 60 day post infection period (p.i.). Cerisola made efforts to minimize the large number of variables that could have affected the results such as the species utilized, methodology of application and examination.

P.-Szumlewicz and Muller (1987) described a variety of species which were identified as successful xenodiagnostic agents in testing hosts with chronic infection by Y Trypanosomal cruzi strain (Panstrongylus megistus, T] pseudomaculata, T] rubrovaria, Rhodnius neglectus). This species could make xenodiagnosis more efficient and reliable.

Bronfen (1989)| suggested the simultaneous use of at least two species of triatomine bugs associated with xenoculture and bloodculture for strain isolation and diagnosis respectively.

P.-Szumlewicz et al. (1988, 1990) emphasized the superiority of silvatic vectors over those from residences as xenodiagnostic agents in experimental hosts with acute and chronic infections caused by seven strains of $T$ ] cruzi, establishing that susceptibility varied according to the species used, giving top priority to $P$. megistus as an xenodiagnostid agent.

The results obtained from this study indicate the superiority of $P$. megistus, T] rubrovarid and T. vitticeps exhibiting the best rates of positivity and density of parasites, followed by $T$. pseudomaculata and $R$. neglectus. In the first place, we tested $P$. megistus, $T$. vitticeps and $R$. neglectus against $T$. infestans and $P$. megistus against $T]$ vitticeps.

\section{MATERIALS AND METHODS}

Xenodiagnosis - Sixteen experiments were performed from June 1984 to July 1992 according to the following scheme: 9 tests between $P$. megistus and $T$. infestans (type I); 3 tests between $T$ ] vitticeps and $T$. infestans (type II); 2 between $R$. neglectus and $T$. infestans (type III) and 2 between $P$. megistus and $T\rfloor$ vitticeps (type IV).

The tests were intended to compare the susceptibilities of two species at a time, using the same patients for each test. Some patients were tested more than once at different times.

The nymphs were divided in wooden boxes and covered with cheese clothes (10 nymphs/box) and kept without food for three weeks; 40 fourth instarl nymphs (20 of each different species tested) were fed for $30 \mathrm{~min}$ on each patient's forearm, except in the first and second tests between P. megistus and T. infestans where 10 and 20 respectively were used for the former and 30 for $T$. infestans.

Fifteen days after feeding, the bugs received a suplementary feeding of chicken blood.

A total of 15,600 bugs were utilized in experiments. From this total 13,281 were examined, 6,503 for T. infestans (total of 14 tests), 3,788 for $P$. megistus (11 tests), 2,3 18 for $T$. vitticeps (5 tests) and 672 for $R$. neglectus (2 tests).

The examination started after a 45 day postinfection period employing optical microscopy (400X) of the suspension of the entire digestive tract which had been ground into a physiological saline. The suspension was prepared after cutting the extreme rear portion of bugs'abdomen, pulling out the digestive tract and grinding it in two or three drops of physiological saline. Thereafter two or more wet films were made to complete the exam.

Dead dried nymphs were not examined.

A test of difference of proportions ( $\mathrm{p} \triangleleft 0.01)$, was used for statistical analysis.

Patients - A total of 161 women and 103 men were tested. The patients were from endemic areas of the Jequitinhonha Valley, in the State of Minas Gerais. In the municipality of Virgem da Lapa| 254 patients (16 tests) were tested and in Coronel Murta 10 patients ( 1 test). The age of patients varied from 5 to 83 years $(38.5 \pm 16.8$ years $)$.

Only 24 patients proved negative for $\mathrm{IgG}$ against $T$. cruzi, shown in immunofluorescent tests and indirect blood aglutination.

\section{RESULTS}

From a total of 392 applied xenodiagnosis $26.28 \%$ were positive. In 161 women 243 tests were applied and in 103 men 149 xenos with positive rates of $27.98 \%$ and $23.49 \%$, respectively. These rates did not show significant differences $(\mathrm{p}<0.01)$, From 161 female patients 52 were positive $(32.30 \%)$ and from 103 male patients 33 were positive $(32.03 \%)$. These rates did not show significant differences $(\mathrm{p}<0.01)$ either.

Xenopositiveness rates are presented in Table I. In tests from type I there were significant differences $(\mathrm{p}<0.01)$ among rates of $P$. megistus $(10.73 \%)$ and $T]$ infestans $(0.98 \%)$. Table I also shows the rates produced when both species tested were positive. The unique case where the percentage of positive patients from the two species tested was statistically superior to the rates of species tested separately, occurred in tests from type IV where $P$. megistus and $T$. vitticeps positive patients produced the rate of $32.35 \%$, significantly higher than the rate of T. vitticeps $(5.88 \%)$.

The nymphs' positive reaction to $P$. megistus, $T]$ vitticeps and $R$. neglectus are compared with $T$. infestans (Table II). There were significant variation $(\mathrm{p}<0.01)$ between the rate of $4.59 \%$ by nymphs of $P \mathrm{~J}$ 

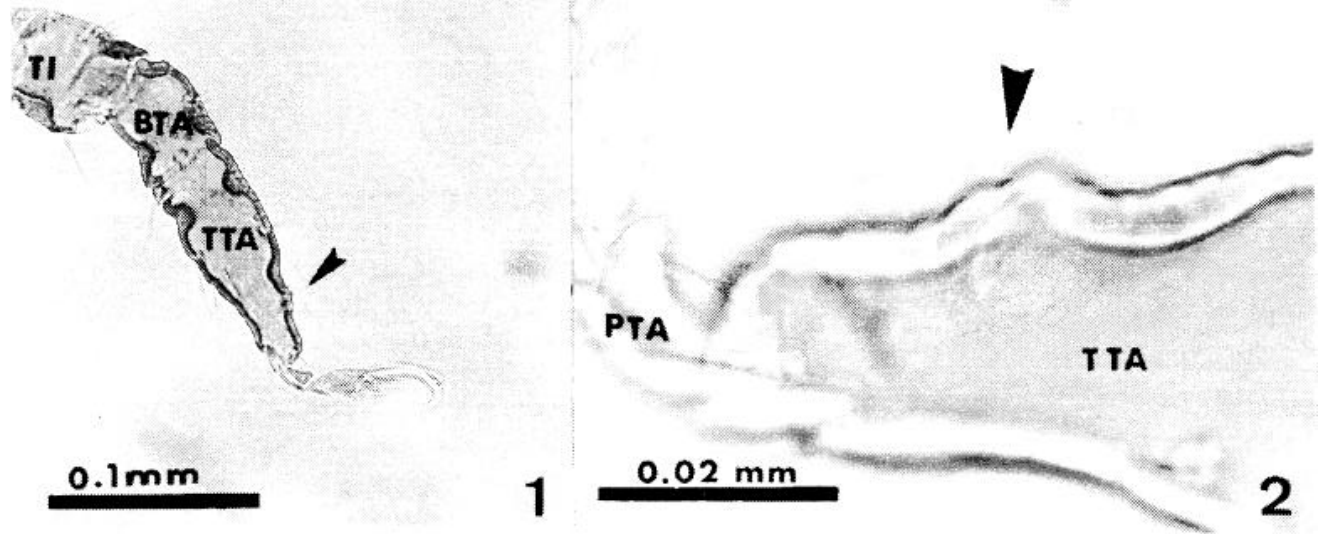

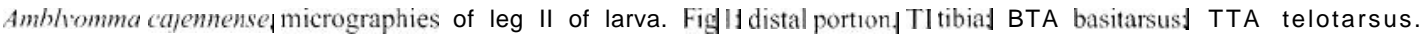
arrow. slitt cuticular structure. Fig 2 detail of slit cuticulart structure. PTA. pretarsus
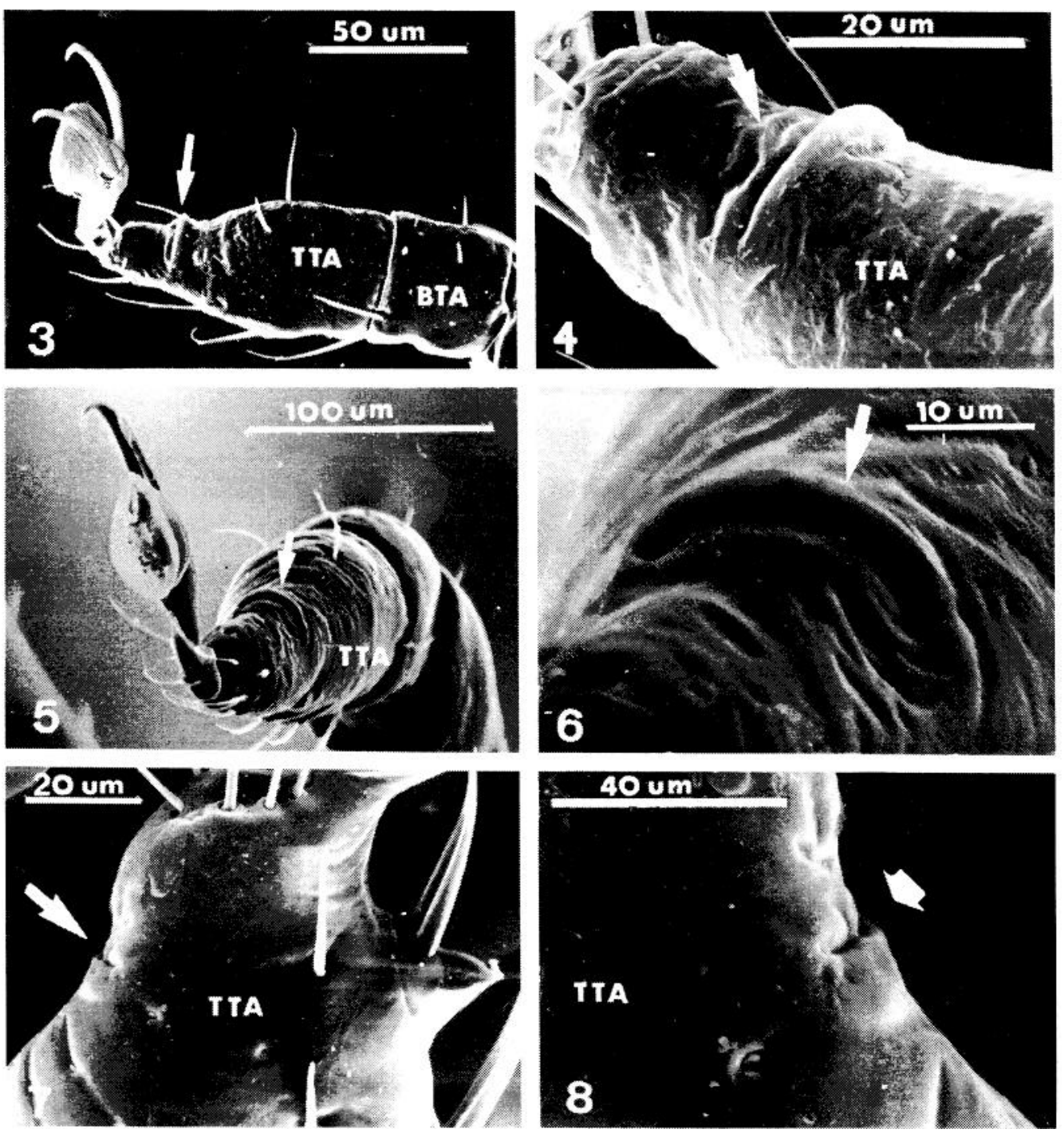

Amblvommd cajennenses electron micrographies of leg II. Fig\$ 3,4 larva Figs 5,6 nymph. Figs 7,8 adult Arrow, slit cuticular structure; TTA telotarsus. BTA basitarsus! 
The contamination rates from each species separately (overall) and the mortality rates are presented in Table IV. The former varied from $1.55 \%$ in $T$. infestans ( 101 in 6,503 examined) to $6.13 \%$ in $T$. vitticeps (142 positive in 2,318 examined). There were significant differences $(\mathrm{p}<0.01)$ between the rates of $T$. vitticeps $(6.13 \%)$ and $P$. megistus (5.44\%) in comparison to T.infestans' rate $(1.55 \%)$. The rates of mortality varied from $13.52 \%$ in $P$. megistus (592 dead in 4,380 sent to endemic area) to $18.95 \%$ in $T$. vitticeps (542 dead in 2,860 sent). The rate demonstrated by $T$. vitticeps is significantly higher than the rate in $P$. megistus $(\mathrm{p}<0.01)$.

Only one patient (woman) negative in serology exhibited positive xenodiagnosis with $P$. megistus $(0.38 \%)$.

\section{TABLE IV}

Relative frequency of mortality and infectivity (overall)

\begin{tabular}{lcc}
\hline \multirow{2}{*}{$\begin{array}{l}\text { Vector } \\
\text { species }\end{array}$} & \multicolumn{2}{c}{ Percentage of } \\
\cline { 2 - 3 } Mortality $_{\text {(overall) }}^{a}$ & $\begin{array}{c}\text { lnfectivit y } \\
\text { (overall) }^{b}\end{array}$ \\
\hline Triatoma infestans & $13.98(7560)$ & $1.55(6503)$ \\
Panstrongylus megistus & $13.52(4380)$ & $5.44(3788)$ \\
Triatoma vitticeps & $1 X .95(2860)$ & $6.13(2318)$ \\
Rhodnius neglectus & $16.00(800)$ & $1.64(672)$ \\
\hline
\end{tabular}

$a$ : number in parenthesis indicates the number of nymphs sent to endemic areas

$b$ : number in parenthesis indicates the total number of examined nymphs

\section{DISCUSSION}

Xenodiagnosis has been well documented in literature. Its low sensibility and divergent results obtained, raised questions about the efficacy of this technique. According to some investigators it could be increased by the use of large numbers of bugs per patient, by repeated exams (previously mentioned) and by the use of vectors capable of supporting rapid development and vigorous multiplication of the few parasites ingested (P.-Szumlewicz \& Muller 1987).

Aiming to improve xenodiagnosis, comparative works were performed to search for a suitable insect model with the above mentioned characteristics (Alvarenga et al. 1977, Barreto et al. 1978, Minter et al. 1978, Marsden 1986, Pereira et al. 1993).

Experimental studies in acute and chronic Chagas disease were developed by P.-Szumlewicz and Muller $(1982,1987)$ using Y strain of T.cruzi. The authors demonstrated that efficiency could be associated with the triatomine species used, enumerating factors of parasite density, giving an accurate portrayal of parasite development. This should be incorporated in screening bugs for xenodiagnosis. They also listed some measures to achieve a reliable xenodiagnostic procedure: the importance of biweekly suplementary feeding (after infection) that could triple the population density of parasites in infected bugs minimizing the probability of recording a false negative result, and stipulated a routine of 45 day post-infection interval in the examination of bugs.

Later, P.-Szumlewicz et al. demonstrated the superiority of silvatic vectors over residential ones in acute (1988) and chronic (1990) infections from seven strains of T.cruzi, calling attention to the phenomenon of vector/parasite relationship, showing the species' capability to respond to chronic infections using different parasite stocks and indicating the most efficient vectors within species tested: P. megistus, T.rubrovaria and $T$. vitticeps. In this study the rates of infected nymphs for $P$. megistus and T.vitticeps were significantly higher than for T. infestans. These results are in accordance with those obtained by P.-Szumlewicz et al. (1990) and Pereira et al. (1993,1996).

In spite of these results various authors continued recommending the use of T.infestans in xenodiagnosis. Chiari (1992) in the "Relatório da VIII Reunião de Pesquisa Aplicada em Doença de Chagas, Uberaba, MC", suggested the use of first and third instar nymphs of Dipetalogaster maximus and T.infestans, respectively. The enthusiasm for D. maximus as a potencial xenodiagnostic agent has been linked to its large size which allows the ingestion of great quantities of infected blood, but up to the moment there is no confirmed relation between infection rates, high density rates of parasites and great quantities of imbebed blood, in chronic Chagas disease.

P.-Szumlewicz et al. (1988) demonstrated that the third instar nymphs of $T$. infestans could ingest more blood than the'first instar nymphs of D. maximus and that, maintenance of a P. megistus colony in the laboratory is easier (fast development, slow locomotion, low mortality and easy to breed under changing enviroments).

Nirschl et al. (1994) analized the susceptibility of T.infestans infected by seven strains of T. cruzi derived from chagasic patients from Triângulo Mineiro, MG, and concluded that this species had low susceptibility, which could explain the low rates of infectivity in xenodiagnosis in the same geographical area.

Results from Tables I-III confirm the existence of significant differences $(p<0.01)$ in rates from xenopositiveness, contagion of nymphs individu- 
ally and general contagion of nymphs (overall) among three species tested in this work. These results demonstrated that the nymphs of T.infestans could be replaced by nymphs of $\mathrm{P}$. megistus and/ or $T$. vitticeps, the best hiterto tested in endemic areas, by our laboratory, in order to upgrade the reliability of xenodiagnosis.

Pereira et al. (1996) also recommended the replacement of T. infestans 'nymphs by P. megistus, which according to the authors increased considerably the xenopositivity in nymphs on the fourth stage. Vector resistance could be a parameter for the species' choice. Data shown in Table IV demonstrate that $P$. megistus has a mortality rate significantly lower than $T$ ] vitticeps.

Additional data from Table I indicated that the association between two different species contributes, in some cases, to the improvement of results. These improvements appear to be specie dependant, related to the phenomenon of parasite specificity in parasite/vector relationship. We think that species considered good vectors with different sensibilities to infection from strains of T. cruzi, should be used, therefore becoming indispensable to screen a significantly large number of good vector species in order to justify the generalization of these procedures.

It was also observed that the positiveness in nymphs of $P\rfloor$ megistus and $T$. infestans in the positive xenodiagnosis of both species was significantly higher than that positive result obtained exclusively from these species separately, which leads us to think about the possibility of the existence of $T$ ] cruzi' subpopulations with different degrees of development in both species.

In the near future xenodiagnosis, which lacks sensibility, could be replaced by K-DNA PCR (Polymerase Chain Reaction Amplification of $\mathrm{Ki}-1$ netoplast Minicircle DNA) in direct parasitological evaluation of chronic chagasic patients. This technique allows caracterization of $T$. cruzi nucleotidic sequences and the replication of synthetic chains giving support to the identification of the parasite with high degrees of sensitivity (Avila et al. 1991, Romanal 1992). According to Avila et al. (1993) this new technique has $100 \%$ sensitivity compared with serologic tests. Maybe the application of xenodiagnosis could be restricted only to strain isolation. Even so, the use of different species used until now have not given satisfatory results (for example T] infestans). Another that can produce better results must be found to enhance the sensibility of xenodiagnosis and consequently its quality. Careful studies on vector-parasite relationship are also urged which require the use of biochemical methods.

\section{ACKNOWLEDGEMENTS}

To Dr Jose Borges Pereira for testing our triatomine species in his patients, to Shirley Maria Cordeiro for typing the manuscript and to Prof. Lidia de Andrade Ribeiro for her assistance in English revision.

\section{REFERENCES}

Alvarenga NJ, Cuba CC, Barreto AC, Marsdenl PD, Macedo V 1977. Valor comparattvo entre Dipetalogaster maximus e Triatoma infestans no diagnósticol parasttologico de pacientes chagasicos crônicos corn sorologia positiva. Resumos do XIII Cong Sod Bras Parasitol, Brasilia, DF, p. 43.

Alvarenga NJ, Bronfen E 1984. Interaçãol do Trypanosoma cruzi corn diferentes vetores uso para| o xenodiagnóstico| Rev Sod Bras Med Trop 17: 145149.

Avila HA, Sigman DS, Cohen LM, Millikan RC, Simpson L 199 1. Polymerase chain reaction amplification of T.cruzl Kinetoplast minicircle DNA isolated from whole blood lysates: diagnosis of chronic Chagas' disease. Mol Biochem Parasitol 48.124212426.

Avila HA, Pereira JB, Thiemann 0, Paiva E, Degrave W, Morel CM, Simpson L 1993. Detection of Trył panosoma cruzi in blood specimens of chronic chagasic patients by Polymerase Chain Reaction Amplification of Kinetoplast minicircle DNA: Comparison with Serology and Xenodiagnosis. JClin Microbiol 31:12421-2426.

Barreto AC, Marsden PD, Cuba CC, Alvarenga NJ 1978. Estudo preliminar de Dipetalogaster maximus (Uhler, 1894) (Triatominae) na técnical do xenodiagnóstico em forma crônical de doençal de Chagas. Rev Ins Med Trop S Pauld 20: 183-189.

Bronfen 1989. Xenodiagndstico: Isolamento do Trypanosoma cruzi na fase crônical da doençal de Chagas. $\mathrm{PhDl}$ Thesis, Instituto de Ciências Biologicas da Universidade Federal de Minas Gerais, 165 pp.

Bronfen E, Dias JPC, Gouveia SC 1984. Infecçãol experimental de Triatoma infestans e Panstrongylus megistus pela cepa Y do Trypanosomal cruzi (Silva e Nussenzweig, 1953). Rev Pat Tropical 13: 1-7.

Brumpt E 1914. Le xenodiagnostic. Application au diagnostic de quelques infection parasitaires et in particulier à la tsrypanosome de Chagas. Bull Sod Path Exot 77: 706-710]

Castro CN, Alves MT, Macedol VO 1983. Importâncial da repetição do xenodiagnóstico para avaliação da parasitemia na frase crônica da doençal de Chagas. Rev Sod Bras Med Trop 16: 98-103.

Cerisola JA, Rohwedder RW, Prado CE 1971. Rendimento del xenodiagnósticol in la infección chagasica crônical humanal utilizando ninfas de diferentes espécies de triatomineos. Boll Chileno de Parasitol 26: 57-58.

Cerisola JA, Rohwedder RW, Segura EL, Del Prado CE, Alvarez M, Martini GJW 1975. El xenodiagnósticol International Symposium in New Approaches in American Trypanosomiases Research, Pan American Health Organization, Belol Horizonte, Session III, B. 4. 
Cerisola JA, Rohwedder RW. Segura EL, Del Prado CE, Alvarez M, Martini GJW 1974. Elxenodiagnóstico. Buenos Aires, Argentina.

Chiari E 1992. Padronizaçào do xenodiagnostico. Rev Soc Bras Med Trop 25 (Supl. III): 40-42.

Dias 1940. Xenodiagnbstico seriados em cães infectados corn amostras venezuelanas de "Schizotrypanum cruzi". Bras Med 52: 859-861.

Little JW, Tay J, Biagi F 1966. A study on the susceptibility of triatomid bugs to some Mexican strains of Trypanosoma cruzi. J Med Ent 3: 252-255.

Marsden PD 1986. Dipetalogaster maxima ou D. maximuscomo agente no xenodiagnostico (Editorial). Rev Soc Bras Med Trop 19: 205-207.

Meckelt GA 1964. A modified procedure of xenodiagnosis for Chagas disease. Am Trop Med Hyg 13: 11-15.

Minter DM, Minter-Goedbloed E, Marshall TF de C 1978. Comparative xenodiagnosis with tree triatominae species ofdifferent host with natural and experimental chronic infections with Trypanosoma (Schizotrypanum cruzi). Trans $R$ Soc Trop Med Hyg 72: X4-91.

Nirschl RA, Soares-Junior JM, Pirani EM, Franciscon JU, Ramirez LE 1994. Suscetibilidade do T.infestans a diferentes cepas do T. cruzi isoladas de diferentes pacientes chagisicos do Triingulo Mineiro. Rev Soc Bras Med Trop 27: 235-239.

Pereira JB, Junqueira ACV, Coura JR 1993. Xenodiagnostico da doença de Chagas crônica. I Aplicação simultdnea de Triatoma infestans $e$ Panstrongylus megistus. In Anais da IX Reuniào Anual de Pesquisa Aplicada em Doença de Chagas, Uberaba, Minas Gerais, p. 110.

Pereira JB, Junqueira ACV, Santos LC, Castro JAF, Araujo IB, Coura JR 1996. Xenodiagnóstico na doença de Chagas crônica. I - Sensibilidade de Panstrongylus megistus e Triatoma infestans. Rev Soc Bras Med Trop 29: 341-347.

Perlowagora-Szumlewicz A, Mulher CA 1982. Studies in search of a suitable experimental insect model for xenodiagnosis of hosts with Chagas' disease. 1 -
Comparative xenodiagnosis in nine triatomonae species with acute infections by Trypanosoma cruzi. Mem Inst Oswaldo Cruz 77: 37-53.

Perlowagora-Szumlewicz A, Muller CA 1987. Studies in search of a suitable experimental insect model for xenodiagnosis of hosts with Chagas' disease. 2 - Attempts to upgrade the reliability and the efficacy of xenodiagnosis in chronic Chagas' disease. Mem Inst Oswaldo Cruz 82: 259-272.

Perlowagora-Szumlewicz A, Muller CA, De Carvalho Moreira CJ 1988. Studies in search of a suitable experimental insect model for xenodiagnosis of hosts with Chagas' disease. 3 - On the interaction of vector species and parasite strain in the reaction of bugs to infection by Trypanosomacnuzi.Rev Sati Públ São Paulo 22: 390-400.

Perlowagora-Szumlewicz A, Muller CA, De Carvalho Moreira CJ 1990. Studies in search of a suitable experimental insect model for xenodiagnosis of hosts with Chagas' disease. 4 -The reflection of parasite stock in the responsiveness of different vector species to chronic infection with different Trypanosoma cruzi stocks. Rev Sai Públ São Paulo 24: 165- 177.

Ryckman RE 1985. The epizootiology of Trypanosoma cruzi, in south-western North America. V: Host-parasite specificity between Trypanosomacruzi and Triatominae (Kinetoplastida : Trypanosomidae) (Hemiptera : Triatominae). J Med Ent 2: 96-99.

Romana AJ 1992. Utilização do PCR no diagnóstico da Doença de Chagas humana. Rev Soc Bras Med Trop 25 (Supl. III): 27-29.

Schenone H, Alfaro E, Rojas A 1974. Bases y rendimento de xenodiagnostico con la infection chagasica humana. Bull Chileno Parasitol 29: 24-26.

Segura EL 1987. Xenodiagnosis, p. 41-45. In RR Brener \& AM Stoka (eds). Chagas' disease vectors, Anatomic and physiological aspects. Volume II CRC Press, Inc., Boca Raton, FA.

Zeledón R 1974. Epidemiology, modes of transmission and reservoir hosts of Chagas' disease. In Ciba Fundation Symposium, Amsterdam, Elsevier, Excerpta Médica 20: 5 1-77. 